\title{
EFEKTIVITAS KONSUMSI NUGGET TEMPE KEDELAI TERHADAP KENAIKAN BERAT BADAN BALITA GIZI KURANG
}

\author{
Mariyam ${ }^{1)}$ Arfiana ${ }^{2)}$ Tuti Sukini ${ }^{3)}$ \\ Email : mariyamalya131@gmail.com
}

\begin{abstract}
The purpose of this research is to analyze the effectiveness of soybean tempeh nuggets consumption to weight gain stunting. This research was conducted in Tlogomulyo Primary Health Care Temanggung. This research is a quasi experimental design with Pretest-Posttest Design. The study population was all children under five with malnutrition status using total sampling technique sampling.

The results showed that consumption of soy tempeh nuggets effective against weight gain stunting in the work area Tlogomulyo Temanggung 2016 with a $p$ value of 0.000 . From the results of the study are expected midwife can improve health services, especially to address malnutrition among children under five by providing health education to mothers about the nutritional needs of toddlers by providing food ingredients derived from soy tempe having a protein content as the one food that can increase the weight toddler body.
\end{abstract}

Keyword : Soy Nugget Tempe, Weight Loss, Nutrition Toddler Less

1) Student of Diploma Programme Midwifery Magelang

2) 3) Lecture of Diploma Programme Midwifery Magelang 
Indonesia sampai saat ini masih dihadapkan pada masalah gizi. Program gizi yang sudah dilaksanakan pada dasarnya mampu menurunkan angka kejadian gizi kurang dan buruk pada balita tapi belum mencapai target yang diharapkan dalam Rencana Pembangunan Jangka Menengah Nasional tahun 2010-2014, yaitu 15\% dan Millenium Development Goals (MDGs) tahun 2015, yaitu $15,5 \%$ bahkan di beberapa daerah prevalensinya diatas angka nasional. Data Riset Kesehatan Dasar (Riskesdas) menunjukkan prevalensi gizi kurang pada balita tahun 2012 adalah $17,9 \%$. Kondisi gizi kurang dan buruk ini menyebabkan risiko balita menderita penyakit infeksi meningkat karena daya tahan tubuh yang rendah.Bahkan kondisi ini dapat menyebabkan kematian.WHO menyatakan kematian balita di negara berkembang, 60\%nya disebabkan gizi buruk (Riskesdas, 2013).

Balita termasuk kelompok rawan gizi, mereka mudah menderita kelainan gizi karena kekurangan makanan yang dibutuhkan.Masalah gizi yang harus dihadapi Indonesia pada saat ini adalah masalah gizi kurang dan gizi lebih.Masalah gizi kurang disebabkan oleh kemiskinan, kurangnya persediaan pangan, sanitasi lingkungan yang kurang baik, kurangnya pengetahuan masyarakat tentang gizi dan kesehatan, sedangkan masalah gizi lebih disebabkan oleh kemajuan ekonomi pada masyarakat disertai dengan kurangnya pengetahuan gizi dan kesehatan (Waryono, 2010).

Status gizi masyarakat dipengaruhi oleh banyak faktor yang kompleks dan satu sama lain saling terkait. Pada level rumah tangga, status gizi anggota keluarga dipengaruhi oleh kemampuan rumah tangga untuk menyediakan pangan yang cukup baik secara kuantitas maupun kualitasnya, pola pengasuhan ibu, pengetahuan gizi dan faktor-faktor sosial budaya (Zuraida, 2009).

Masalah gizi di Indonesia pada umumnya masih didominasi oleh masalah masalah Kurang Energi Protein (KEP), anemia besi, masalah gangguan Akibat Kekurangan Yodium (GAKY), masalah Kurang Vitamin A (KVA), dan masalah obesitas terutama di kota-kota besar.Hal ini berarti Indonesia mengalami masalah gizi ganda yang artinya sementara masalah gizi kurang belum dapat teratasi secara menyeluruh, sudah muncul masalah baru yaitu berupa gizi lebih (Supariasa, dkk, 2012)

Hasil data status gizi balita berdasarkan RISKESDAS (Riset Kesehatan Dasar) 2010, secara nasional, prevalensi berat badan kurang pada 2010 adalah $17,9 \%$ yang terdiri dari $4,9 \%$ gizi buruk dan 13,0 gizi kurang, meningkat dari keadaan tahun 2007 yaitu sebesar 12,2 \%. Bila dibandingkan dengan pencapaian MDG (Millenium Development Goals) tahun 2015 yaitu 15,5\% maka prevalensi berat badan kurang secara nasional harus diturunkan minimal sebesar $2,4 \%$ dalam periode 2011 2015, sedangkan status gizi balita di Propinsi Jawa Tengah pada tahun 2012 yaitu Balita Gizi Buruk tahun 2012 berjumlah $1.131 \quad(0,06 \%)$ menurun apabila dibandingkan tahun 2011 sejumlah $3.187(0,10 \%)$ (Dinas Kesehatan Propinsi Jawa Tengah, 2013).Jumlah Gizi kurang di Wilayah Kerja Puskesmas Tlogomulyo Kabupaten Temanggung pada tahun 2015 dari 29.968 balita, sebanyak 33 
balita mengalami gizi kurang,7 balita mengalami gizi buruk (profil Puskesmas Tlogomulyo 2015)

Usia balita merupakan usia pra sekolah dimana seorang anak akan mengalami tumbuh kembang dan aktivitas yang sangat pesat dibandingkan dengan ketika masih bayi, kebutuhan zat gizi akan meningkat. Sementara pemberian makanan juga akan lebih sering. Pada usia ini, anak sudah mempunyai sifat konsumen aktif, yaitu mereka sudah bisa memilih makanan yang disukainya. Seorang ibu yang telah menanamkan kebiasaan makan dengan gizi yang baik pada usia dini tentunya sangat mudah mengarahkan makanan anak, karena dia telah mengenal makanan yang baik pada usia sebelumnya. Oleh karena itu, pola pemberian makanan sangat penting diperhatikan.Secara umum faktor yang mempengaruhi terbentuknya pola makan adalah faktor ekonomi, sosial budaya, agama, pendidikan, dan lingkungan (Sulistyoningsih, 2011).

Pada anak yang kurang gizi, daya tahan tubuhnya rendah sehingga anak sering terkena penyakit infeksi. Akibatnya anak tersebut tidak dapat tumbuh dan berkembang secara optimal dimana anak tampak kurus dan pendek, terutama pada masa usia bawah lima tahun (balita) banyak yang menderita kurang energi protein (KEP). Selain itu, anak kurang gizi pertumbuhan dan perkembangan otaknya juga tidak optimal, sehingga dapat menurunkan kecerdasan anak. Anak akan tumbuh dan berkembang menjadi remaja dan pada usia dewasa kurang berprestasi serta produktifitas rendah yang akhirnya menjadi lanjut usia (lansia) yang kurang gizi, sakitsakitan yang menjadi beban bagi keluarga dan masyarakat. Kondisi tersebut akan berdampak pada mutu sumber daya manusia yang rendah (Sundari, 2014).

Menurut Astuti (2014) protein tempe tergolong mudah dicerna sehingga protein dapat digunakan untuk menambah berat badan terutama pada balita.Tempe yang dibuat dari kacang kedelai telah dimanfaatkan sebagai sumber protein nabati. Komposisi tempe kedelai menunjukkan defisit pasangan asam amino metionin-sistin, secara menyeluruh mengandung unsur zat gizi yang cukup tinggi: $25 \%$ protein (17 gram protein/100gram), 5 $\%$ lemak, $4 \%$ karbohidrat dan $60 \%$ air, sumber vitamin B12 yang cukup tinggi, rendah lemak, bebas kolesterol.

Cara mengatasi balita dengan gizi kurang salah satunya dengan cara memenuhi konsumsi makanan setiap hari secara bervariasi, menganjurkan pada orang tua balita agar balitanya mengurangi jajanan dengan aroma gurih dan manis, karena hal tersebut akan memberi rasa kenyang sehingga asupan gizi tidak terpenuhi, upaya untuk meningkatkan berat badan balita adalah dengan pemberian PMT yang mengandung tinggi protein dan tinggi kalori sesuai dengan berat badan balita sehingga dapat memenuhi kebutuhan gizinya (Atmarita, 2005). Salah satu jenis PMT yang memenuhi kebutuhan tersebut adalah dengan pemberian olahan tempe kedelai, agar olahan tempe kedelai tersebut bisa terkonsumsi secara maksimal, kemudian kita modifikasi menjadi bentuk nugget, dengan penyajian lain diharapkan balita menjadi tertarik sehingga mempunyai kemauan untuk mengkonsumsinya.

Pemberian konsumsi nugget tempe kedelai, diharapkan semua balita 
terutama yang mengalami gizi kurang akan mengalami kenaikan berat badan, sehingga dapat meningkat status gizinya menjadi gizi normal.Di posyandu, Balita gizi kurang sudah mendapatkan PMT berupa biskuit, dengan PMT tersebut belum menunjukkan kenaikan berat badan, sehingga balita dengan status gizi kurang belum dapat teratasi, hal tersebut dikwatirkan akan berlanjut menjadi gizi buruk.Dengan pemberian nugget tempe kedelai akan mengantisipasi status gizi balita kurang tidak menurun menjadi gizi buruk, dan diharapkan status gizi balita akan meningkat sehingga masalah gizi kurang dapat teratasi

Tujuan dari penelitian ini adalah untuk mengetahui efektifitas konsumsi nugget tempe kedelai terhadap kenaikan berat badan balita gizi kurang di wilayah kerja Puskesmas Tlogomulyo Kabupaten Temanggung tahun 2016.

\section{METODE PENELITIAN}

Penelitian ini merupakan bentuk penelitian kuantitatif dengan metode yang digunakan dalam penelitian ini adalah Quasi eksperiment dengan Pretest-Postest Design. Tujuan dari penelitian ini adalah untuk menganalisis efektifitas konsumsi nugget tempe kedelai terhadap kenaikan berat badan balita gizi kurang. Populasi penelitian ini adalah seluruh anak balita dengan status gizi kurang menggunakan teknik sampling total sampling dengan jumlah sampel sebanyak 33 responden dengan menggunakan uji T-Test Dependent dengan kepercayaan sebanyak $95 \%$.

\section{HASIL PENELITIAN}

Hasil penelitian menunjukkan rerata berat badan balita gizi kurang sebelum mengkonsumsi nugget tempe kedelai 9,9945 $\mathrm{Kg}$ dengan berat badan balita terendah $7,87 \mathrm{Kg}$ dan berat badan balita tertinggi 13,01 Kg. Hasil penelitian ini sama dengan hasil penelitian Ardiana (2011) yang menunjukkan bahwa sebelum mendapatkan perlakuan tahu-tempe semua balita mengalami gizi buruk, dimana pengukuran status gizi balita secara sederhana dapat diketahui dengan membandingkan antara berat badan menurut umur maupun menurut panjang badannya denganrujukan (standar) yang telah ditetapkan.

Berat badan balita normal menurut Supariasa (2012) dimana keadaan kesehatan baik dan keseimbangan antara konsumsi dan kebutuhan zat gizi terjamin, maka berat badan berkembang mengikuti pertambahan umur. Sebaliknya dalam keadaan abnormal, terdapat 2 kemungkinan perkembangan berat badan yaitu dapat berkembang cepat atau lebih lambat dari keadaan normal.

Berdasarkan hasil penelitian menunjukkan rerata berat badan balita gizi kurang sesudah mengkonsumsi nugget tempe kedelai $10,1855 \mathrm{Kg}$ dengan berat badan terendah $8 \mathrm{Kg}$ dan berat badan tertinggi $13,25 \mathrm{Kg}$ dengan rata-rata kenaikan berat badan adalah 0,20 Kg. Responden yang mengalami kenaikan berat badan sebanyak 28 responden dan yang tidak mengalami peningkatan berat badan sebanyak 5 responden. Hasil penelitian ini sama dengan dengan hasil penelitian Ardiana (2011) yang juga menunjukkan bahwa tampak terjadi peningkatan berat badan ratarata sebesar $0.4438 \mathrm{~kg}$ setelah dilakukan perlakuan pemberian tahu- 
tempe selama 1 bulan. Peningkatan berat badan dapat disebabkan karena tercukupinya kebutuhan protein menjadi salah satu alternatif cara menekan kasus gizi buruk. Protein tersedia dalam protein hewani dan protein nabati. Tahu dan tempe merupakan makanan tradisional Indonesia yang mengandung protein nabati. Tahu dan tempe merupakan makanan tradisional Indonesia yang mengandung protein nabati yang dianjurkan untuk dikonsumsi sekitar 150-300 gram bahan matang/hari pada diet 1500-2100 kalori. Kandungan protein pada tempe adalah $18 \mathrm{mg}$ per $100 \mathrm{gr}$, sedangkan pada tahu adalah $8 \mathrm{mg}$ per 100 gr. Kebutuhan protein anak usia < 1 tahun adalah 2-3 gr / kgBB/hari, kebutuhan anak 1-6 tahun adalah 1,5-2,5 gr / kgBB/hari dan pada penelitian Ardiana (2011) diberikan sebanyak 200 gram/hari selama 1 bulan.

Hasil penelitian ini yang juga menunjukkan ada peningkatan berat badan setelah mengkonsumsi nugget tempe kedelai dengan jumlah yang diberikan dengan ketentuan tempe 200 gr untuk kelompok umur 1-3 tahun dan $300 \mathrm{gr}$ untuk kelompok umur 4-5 tahun dalam bentuk nugget@ 30 gr tempe dalam satu hari yang diberikan selama 14 hari dengan hasil rata-rata peningkatan berat badan $0,20 \mathrm{~kg}$, yang berarti sama dengan hasil penelitian Ardiana (2011) yang dilakukan pemberian tahu-tempe dengan komposisi yang sama selama 1 bulan mengalami peningkatan sebesar $0,4438 \mathrm{~kg}$. Pemberian Nugget tempe juga dapat meningkatkan berat badan balita karena menurut Joe (2011) komposisi gizi tempe, baik kadar protein, lemak dan karbohidratnya mudah dicerna di dalam tubuh, karena adanya enzim pencernaan yang dihasilkan oleh kapang tempe.

Tempe dapat meningkatkan berat badan balita karena kandungan proteinnya tinggi, yang menurut Almatsier (2005) metabolisme protein dimulai setelah protein dipecah menjadi asam amino, asam amino akan memasuki siklus TCA bila dibutuhkan sebagai sumber energi atau bila berada dalam jumlah berlebih dari yang dibutuhkan untuk sistesis protein. Mula-mula asam amino akan mengalami deaminase, yaitu melepas gugus amino. Proses ini membutuhkan vitamin B6 dalam bentuk PLP. Asam amino kemudian dikatabolisme melalui tiga cara, kira-kira separuh dari asam amino yaitu alanin, serin, glisin, sistein, metionim, dan triptofan diubah menjadi piruvat. Kurang lebih separuh lagi yaitu fenilalanin, tirosin, leusin, isoleusin dan lisin, seperti halnya asam lemak di ubah menjadi asetil KoA. Sisa asam amino kecuali asam aspartat diubah menjadi asam glutamat, dideaminase dan langsung memasuki siklus TCA. Asam amino yang diubah menjadi piruvat dapat diubah menjadi glukosa. Oleh karena itu dinamakan asam amino glukogenik. Asam amino yang diubah menjadi asetil KoA dapat digunakan untuk memperoleh energi atau dapat diubah menjadi lemak, asam amino ini dinamakan ketogenik. Asam amino yang langsung masuk ke dalam siklus TCA juga merupakan asam amino glukogenik, karena dapat menghasilkan energi atau keluar dari siklus dan diubah menjadi glukosa.

Hasil uji Statistik pada pengukuran efektivitas konsumsi nugget tempe kedelai terhadap kenaikan berat badan balita gizi kurang di wilayah kerja Tlogomulyo Kabupaten Temanggung 
tahun 2016 diperoleh hasil $p$ value sebesar 0,000 yang artinya $p$ value < 0,05 , maka Ha diterima dan Ho ditolak, yang artinya konsumsi nugget tempe kedelai efektif terhadap kenaikan berat badan balita gizi kurang di wilayah kerja Tlogomulyo Kabupaten Temanggung tahun 2016. Hasil penelitian ini sama dengan hasil penelitian Ardiana (2011) yang menunjukkan ada pengaruh pemberian tahu-tempe terhadap peningkatan berat badan bayi penderita gizi buruk. Pemberian tahu tempe dapat meningkatkan berat badan balita gizi buruk menurut Ardiana (2011) karena tahu dan tempe merupakan makanan tradisional Indonesia yang mengandung protein nabati. Protein dapat digunakan untuk menyediakan energi, tetapi karena peranan protein yang esensial dalam pertumbuhan, pemeliharaan, dan perbaikan, maka kalori yang cukup harus disediakan dalam diet dari sumber nonprotein. Protein dihemat sebagai sumber energi ketika ada karbohidrat yang cukup dalam diet untuk memenuhi kebutuhan energi tubuh.

Hasil penelitian Gultom (2013) juga menunjukkan ada perbedaan yang bermakna antara rata-rata berat badan sebelum intervensi dan sesudah intervensi pada kelompok yang mendapatkan perlakuan cookies substitusi tepung tempe Standar Nasional Indonesia (SNI) sebanyak $100 \mathrm{gr}$ atau 21 keping yang menyumbangkan energi 468,450 kkal dan protein 6,69 gr. Pemberian cookies substitusi tepung tempe menurut hasil penelitian Gultom (2013) dapat meningkatkan berat badan balita karena cookies tempe mengandung zat gizi mikro dan makro yang sangat penting dibutuhkan oleh tubuh. Hal ini menurut Alamatsier (2004) sesuai dengan fungsi masing-masing dalam tubuh, maka pengaruh yang disebabkan terhadap pertumbuhan anak batita gizi kurang sangat bermakna dalam hal ini hal ini terlihat dari pengaruhnya lebih baik terhadap berat badan. Zat gizi mikro yang berperanan penting dalam proses pertumbuhan adalah fosfor, kalsium seng, di mana peranannya bukan saja disebabkan karena efeknya pada reflikasi sel dan metabolisme asam nukleat, tetapi juga karena seng berperan sebagai mediator dari aktifitas hormon pertumbuhan. Selain itu seng juga berperan sebagai mediator potensial pertahanan tubuh terhadap infeksi dan mempunyai fungsi fisiologis pada pengecapan dan nafsu makan. Kekurangan seng dalam waktu yang singkat pada anak balita mengakibatkan penurunan nafsu makan, sedangkan dampak jangka panjangnya akan terjadi gangguan pertumbuhan dan perkembangan, termasuk mineral mikro lainnya.

Hasil penelitian ini yang juga menunjukkan konsumsi nugget tempe kedelai efektif terhadap kenaikan berat badan balita gizi kurang. Hal ini sesuai dengan pendapat Atmarita (2005) bahwa untuk mengatasi balita dengan gizi kurang salah satunya dengan cara memenuhi konsumsi makanan setiap hari sehingga asupan gizi terpenuhi, upaya untuk meningkatkan berat badan balita adalah dengan pemberian PMT yang mengandung tinggi protein, salah satu jenis PMT yang memenuhi kebutuhan tersebut adalah dengan pemberian olahan tempe kedelai, agar olahan tempe kedelai tersebut bisa terkonsumsi secara maksimal, kemudian kita modifikasi menjadi 
bentuk nugget, dengan penyajian lain diharapkan balita menjadi tertarik sehingga mempunyai kemauan untuk mengkonsumsinya.

Nugget tempe kedelai merupakan produk olahan dalam bentuk beku yang bersifat siap untuk dimasak, Berdasarkan hasil penelitian Novelina tentang Meningkatkan Nilai Tambah Produk Tempe Dengan Diverifikasi Produk Menjadi Nugget. Kandungan gizi yang ada dalam Nugget tempe setelah melalui proses pengolahan tidak mengurangi nilai gizinya, bahkan lebih bergizi karena mengandung protein tinggi dan rendah lemak. Mutu protein ditentukan oleh jenis dan proporsi asam amino yang dikandungnya. Protein komplit atau protein dengan nilai biologi tinggi atau bermutu tinggi adalah protein yang mengandung semua jenis asam amino esensial dalam proporsi yang sesuai untuk keperluan pertumbuhan (Almatsier,2005).

Menurut Joe (2011) komposisi gizi tempe, baik kadar protein, lemak dan karbohidratnya mudah dicerna di dalam tubuh, karena adanya enzim pencernaan yang dihasilkan oleh kapang tempe. Sehingga sangat baik untuk diberikan kepada segala kelompok umur. Selama proses fermentasi terdapat tedensi peningkatan derajat ketidakjenuhan terhadap lemak, sehingga asam lemak PUFA (polyunsaturated fatty acids) meningkat jumlahnya yang akan mengakibatkan penurunan terhadap kandungan kolesterol serum sehingga dapat menetralkan efek negatif kolesterol dalam tubuh.

Tercukupinya kebutuhan protein menjadi salah satu alternatif cara menekan kasus gizi kurang. Protein tersedia dalam protein hewani dan protein nabati. Tahu dan tempe merupakan makanan tradisional Indonesia yang mengandung protein nabati. Bahan makanan dalam piramida Bahan Makanan dikelompokkan menjadi empat kelompok yaitu kelompok warna hijau, kuning,jingga dan merah. Protein termasuk dalam kelompok jingga, yang menjadi sumber bahan pembangun untuk perbaikan jaringan tubuh, pertumbuhan dan metabolesme. Kandungan protein pada tempe adalah $20,8 \mathrm{mg}$ per $100 \mathrm{gr}$. Kebutuhan protein bagi balita adalah $10-15 \%$ dari total energi (Herqutanto, 2014). Protein yang dimakan sehari-hari menurut Pudjiadi (2005) terdiri dari 20 macam asam amino yang setelah dicerna dan diserap digunakan untuk sintesis protein sel, protein fungsional seperti hormon dan enzim, dan protein pengangkut seperti transferrin. Asamasam amino lainnya yang tidak termasuk esensial disebut asam amino non-esensial. Asam amino yang berlebihan tidak dapat disimpan, melainkan diubah menjadi energi atau dikonversi menjadi karbohidrat atau lemak.

Fungsi protein bagi tubuh manusia yang paling utama menurut Sediaoetama (2003) adalah untuk pembentukan sel-sel pada tubuh, dan protein akan menjadi makanan otot supaya dapat tumbuh dan berkembang sehingga jika otot terpenuhi oleh protein maka otot akan terpelihara dengan baik. Protein juga membantu metabolisme glukosa dalam tubuh, sehingga dapat membantu meningkatkan pembentukan sel-sel pada tubuh.

Pemberian nugget tempe kedelai pada penelitian ini pada prinsipnya adalah memberikan konsumsi protein 
nabati, karena pada usia balita kebutuhan protein lebih tinggi daripada kebutuhan lemak dan karbohidrat. Pemberian nugget tempe hanya bersifat tambahan karena pemberian nugget tempe kedelai tidak berdasarkan berat badan anak. Responden mendapat nugget tempe kedelai sesuai kelompok umur, $200 \mathrm{gr}$ untuk balita 1-3 tahun, $300 \mathrm{gr}$ untuk balita 4-5 tahun. Hasil dari pemberian nugget tempe kedelai menunjukkan adanya peningkatan meskipun sangat kecil (Rerata 10,1855). Hal ini dapat menjadi gambaran bahwa nugget tempe kedelai efektif meningkatkan berat badan balita gizi kurang, karena menurut Ardiana (2011) pada anak todler dan usia pra sekolah, kebutuhan kalori lebih rendah, tetapi terjadi peningkatan jumlah protein dalam hubungan dengan berat badan. Tercukupinya kebutuhan protein menjadi salah satu alternatif cara menekan kasus gizi buruk.

Peningkatan berat badan responden juga ditunjang dengan pola makan yang baik. Pola pengasuhan anak berpengaruh pada timbulnya gizi kurang. Anak yang diasuh ibunya sendiri dengan kasih sayang,maka anak akan lebih terjamin pola makan yang sesuai kebutuhannya. Protein dapat digunakan untuk menyediakan energi, tetapi karena peranan protein yang esensial dalam pertumbuhan, pemeliharaan dan perbaikan, maka kalori yang cukup harus disediakan dalam diet dari sumber non protein. Protein dihemat sebagai sumber energi ketika ada karkohidrat yang cukup dalam diet untuk memenuhi kebutuhan energi tubuh. (Ardiana, 2011)

Kenaikan berat badan balita setelah diberikan intervensi disebabkan ibu lebih memperhatikan dalam pemberian makanan tambahan berupa nugget tempe yang tepat disamping makanan sehari-hari, baik jumlah/takaran serta cara pemberiannya. Pertumbuhan yang tetap pada balita gizi kurang setelah intervensi penelitian disebabkan karena selama kurun waktu 14 hari intervensi, balita tersebut menderita sakit seperti ISPA yang dapat menurunkan nafsu makan balita, sehingga tidak terjadi peningkatan berat badan.

\section{SIMPULAN}

Rerata berat badan balita gizi kurang sebelum mengkonsumsi nugget tempe kedelai $9,9945 \mathrm{Kg}$ dengan berat badan terendah $7,87 \mathrm{Kg}$ dan berat badan tertinggi $13,01 \mathrm{Kg}$.

Rerata berat badan balita gizi kurang sesudah mengkonsumsi nugget tempe kedelai $10,1855 \mathrm{Kg}$ dengan berat badan terendah $8 \mathrm{Kg}$ dan berat badan tertinggi $13,25 \mathrm{Kg}$ dengan rata-rata kenaikan berat badan adalah $0,19 \mathrm{Kg}$.

Konsumsi nugget tempe kedelai efektif terhadap kenaikan berat badan balita gizi kurang di wilayah kerja Tlogomulyo Kabupaten Temanggung tahun 2016 dengan $p$ value 0,000

\section{SARAN}

Ibu dengan balita gizi buruk sebaiknya mengasuh balita dengan baik dengan cara memberikan asupan makanan tambahan berupa olahan tempe sebagai lauk maupun cemilan yang kandungan proteinnya tinggi sehingga balita cepat kembali pulih ke berat badan yang normal.

Bidan dapat meningkatkan pelayanan kesehatan khususnya untuk mengatasi gizi kurang pada balita dengan cara memberikan pendidikan 
kesehatan pada ibu balita tentang kebutuhan gizi balita dengan memberikan bahan makanan yang bersumber dari tempe kedelai yang mempunyai kandungan protein sebagai salah satu bahan makanan yang dapat meningkatkan berat badan balita

Peneliti selanjutnya diharapkan dapat melanjutkan penelitian ini dengan mengukur efektivitas konsumsi nugget tempe kedelai terhadap kenaikan berat badan balita gizi kurang dengan jumlah sampel yang lebih besar dengan harapan data yang didapatkan berdistribusi dan hendaknya memperhatikan dan mengendalikan variabel confounding, seperti penyakit infeksi yang mungkin diderita anak, ketahanan pangan keluarga, pola pengasuhan anak, serta pelayanan kesehatan dan kesehatan lingkungan yang mempengaruhi status gizi balita sehingga tidak diketahui penyebab lain dari peningkatan status gizi balita

\section{DAFTAR PUSTAKA}

Ardiana. (2011). Pengaruh Pemberian Tahu-Tempe Terhadap

Peningkatan Peningkatan Berat Badan Bayi Penderita Gizi Buruk di Kabupaten Jember. Jurnal Keperawatan Soedirman (The Soedirman Journal of Nursing), Volume 6, No.2, Juli 2011.

Anggraini. (2011). Pengaruh Pemberian Makanan Tambahan Pemulihan (PMT-P) Terhadap Pertumbuhan Balita Bawah Garis Merah (BGM) di Puskesmas Kota Wilayah Selatan Kediri. Jurnal STIKES RS. Baptis Kediri Volume 4, No. 1, Juli 2011
Atmarita. (2005). Daftar Komposisi Bahan Makanan. Jakarta : PERSAGI

Atmawikarta. (2007). Pengaruh Pemberian Makanan Pendamping Air Susu Ibu (MP-ASI) Formula Tempe Terhadap Diare, Aktivitas Fisik, dan Pertumbuhan, Bayi Status Gizi Baik Usia 6-12 Bulan di Bogor Jawa Barat. Gizi Indon 2007,30(2):73-97

Astuti. 2014. Komposisi Zat Gizi Tempe yang Difortifikasi Zat Besi dan Vitamin A pada Tempe Mentah dan Matang. AGRITECH, Vol. 34, No. 2, Mei 2014.

BSN. (2012). Tempe Persembahan Indonesia untuk Dunia. Jakarta : Badan Standardisasi Nasional

Dinkes Jateng. (2012). Profil Kesehatan Jawa Tengah Tahun 2012. Semarang : Dinkes.

Gultom. (2013). Pengaruh Pemberian Cookies Substitusi Tepung Tempe Terhadap Pertumbuhan Anak Batita Gizi Kurang di Kelurahan Pakuan Baru Kota Jambi Tahun 2013. Tesis. Medan : Universitas Sumatera Utara

Joe. (2011). 101 Keajaiban Khasiat Kedelai. Yogyakarta : Andi

Moehji. (2009). IImu Gizi, Penanggulangan Gizi Buruk. Jakarta : Bhatara Niaga Media.

Novelina. (2010). Meningkatkan Nilai Tambah Produk Tempe dengan Diversifikasi Produk Menjadi Nugget. FTP Universitas Andalas

Nursalam Dkk. (2005). Asuhan Keperawatan Bayi dan Anak (untuk perawat dan bidan). Jakarta : Salemba Medika. 
Prayudini. 2015. Tutorial Membuat Hamburger Tempe.

Purwaningsih. 2012. Cara Pembuatan Tahu dan Manfaat Kedelai. Jakarta : Ganeca

Riskesdas. 2013. Riset Kesehatan Dasar Indonesia Tahun 2013. Jakarta : Kemenkes RI.

Sugiyono. (2007). Statistika untuk Penelitian. Bandung : Alfabeta.

Sulistyoningsih, H. (2011). Gizi Untuk Kesehatan Ibu dan Anak. Yogyakarta : Graha IImu

Supatmi. (2008). Pengaruh Pemberian Makanan Tambahan pada Balita Kurang Energi Protein (KEP) Pengunjung Balai Penelitian dan Pengembangan Gangguan Akibat kekurangan lodium (BPP GAKI) Magelang. PGM 2008: 31 (2)

Supariasa. (2012). Penilaian Status Gizi. Jakarta : EGC.

Susianto. (2015). Fakta Ajaib Khasiat Tempe. Jakarta : penebar Plus

Waryono. (2010). Gizi Reproduksi. Yogyakarta : Pustaka Rihama.

Zuraida. (2009). Pengaruh Tingkat Pengetahuan dan Sikap Gizi lbu Terhadap Asupan Makanan Balita. Hasil Penelitian dan Pengabdian Kepada Masyarakat. Lampung : Unila. 